\title{
The association of serum metabolites with clinical disease during the transition period
}

\author{
N. Chapinal, ${ }^{\star} \dagger$ M. Carson, ${ }^{*}$ T. F. Duffield, ${ }^{*}$ M. Capel,‡ S. Godden,§ M. Overton,\# J. E. P. Santos, $\|^{2}$ \\ and S. J. LeBlanc* \\ *Department of Population Medicine, University of Guelph, Ontario, Canada, N1G 2W1 \\ †Animal Welfare Program, University of British Columbia, BC, Canada, V6T 1 Z4 \\ $\ddagger$ Perry Veterinary Clinic, Perry, NY 14530 \\ $\S$ Department of Veterinary Population Medicine, University of Minnesota, St. Paul 55108 \\ \#Department of Population Health, University of Georgia, Athens 30602 \\ IIVeterinary Medicine Teaching and Research Center, University of California-Davis, Tulare 93274
}

\section{ABSTRACT}

The objective of this observational field study was to validate the relationship of serum concentrations of nonesterified fatty acids (NEFA), $\beta$-hydroxybutyrate (BHBA), and calcium with disease in early lactation across different management systems. Fifty-five Holstein freestall dairy herds located across the United States and Canada were selected and visited weekly for blood sample collection from 2,365 cows. Only diseases that were consistently recorded across herds and blood samples collected before the disease occurred were considered. Metabolite concentrations in serum in $\mathrm{wk}-1$ relative to calving were considered as predictors of retained placenta (RP) and metritis, and metabolite concentrations in serum in wk -1 and wk +1 relative to calving were considered as predictors of displaced abomasum (DA). For each disease, each metabolite, and week of sampling in the case of DA, a critical threshold was calculated based on the highest combined sensitivity and specificity and used to categorize the serum concentrations into high and low risk categories. Multivariable logistic regression models were built for each disease of interest and week of sampling, considering cow as the experimental unit and herd as a random effect. Cows with precalving serum NEFA concentrations $\geq 0.3 \mathrm{mEq} / \mathrm{L}$ were more likely to develop RP [odds ratio $(\mathrm{OR})=1.8 ; 95 \%$ confidence interval $(\mathrm{CI})=1.3$ to 2.6$]$ and metritis $(\mathrm{OR}=1.8 ; 95 \%$ $\mathrm{CI}=1.5$ to 2.9$)$ after calving than cows with lower NEFA concentrations. Precalving NEFA $\geq 0.5 \mathrm{mEq} / \mathrm{L}$ $(\mathrm{OR}=2.4 ; 95 \% \mathrm{CI}=1.5$ to 3.7$)$, postcalving NEFA $\geq 1.0 \mathrm{mEq} / \mathrm{L}(\mathrm{OR}=2.7 ; 95 \% \mathrm{CI}=1.7$ to 4.4$)$, and postcalving calcium $\leq 2.2 \mathrm{mmol} / \mathrm{L}(\mathrm{OR}=3.1 ; 95 \%$ CI

Received December 7, 2010.

Accepted June 2, 2011.

${ }^{1}$ Corresponding author: nchapinal@yahoo.com

${ }^{2}$ Current address: Department of Animal Science, University of Florida, Gainesville 32611.
$=1.9$ to 5.0) were associated with subsequent risk of DA. In conclusion, elevated serum NEFA concentrations within $1 \mathrm{wk}$ before calving were associated with increased risk of RP, metritis, and DA after calving. Serum NEFA and calcium concentrations in the $2 \mathrm{wk}$ around calving in combination were associated with the risk of DA.

Key words: nonesterified fatty acid, $\beta$-hydroxybutyrate, hypocalcemia, displaced abomasum

\section{INTRODUCTION}

Maintaining health and productivity in the transition period is one of the most difficult tasks for dairy herds. Approximately $75 \%$ of disease in dairy cows typically happens in the first month after calving (LeBlanc et al., 2006). Negative energy balance plays a critical role in many diseases that occur during the transition period (Herdt, 2000). In the days before calving, cows experience a substantial decrease in DMI of up to $30 \%$ (Hayirli et al., 2002). Immediately after calving, the homeorhetic drive to increase milk production coupled with inadequate DMI require the use of energy from body fat stores, which are mobilized as NEFA (Bauman and Currie, 1980). Stresses associated with social group changes or unfortunate environmental conditions in the transition period can cause NEFA release through epinephrine secretion (Herdt, 2000). Most NEFA are metabolized in the liver completely into acetyl-coA, incompletely into ketone bodies such as BHBA, or reesterified into triglycerides. Nonesterified fatty acids contribute importantly to milk fat. Elevated precalving NEFA and decreased DMI were associated with impaired neutrophil function (Hammon et al., 2006), which decreases the first line of defense against infectious agents. Elevated serum NEFA in the week before calving and elevated serum NEFA and BHBA in the first week after calving were associated with displaced abomasums (DA; Cameron et al., 1998; LeBlanc et 
al., 2005; Ospina et al., 2010). Elevated precalving cholesterol and NEFA were associated with a greater risk of retained placenta (RP; LeBlanc et al., 2004; Quiroz-Rocha et al., 2010). Similarly, elevated precalving concentrations of NEFA were associated with an increased risk of uterine disease (Hammon et al., 2006). Furthermore, cows that developed severe metritis spent less time feeding and consumed less feed compared with healthy cows, beginning 2 wk before calving (Huzzey et al., 2007). A study in a single herd reported that subclinical hypocalcemia at calving was a risk factor for DA (Massey et al., 1993).

Frequent monitoring of DMI would be a useful tool to screen cows for disease risk in the transition period (Huzzey et al., 2007; Goldhawk et al., 2009). Measurement of individual DMI is complicated in freestall barns. Timely measurement of circulating concentrations of certain metabolites may provide surrogate information on metabolic health and disease risk. Previous studies have shown the usefulness of cow-side ketone tests in screening programs for identifying subclinical ketosis and disease risk in the first 2 wk of lactation (Carrier et al., 2004). Knowing which metabolites to measure at what time, and how to interpret the results, would be useful to predict subsequent health and performance.

Several studies have reported on cow-level associations of NEFA or BHBA with health and production (LeBlanc et al., 2005; Duffield et al., 2009; Ospina et al., 2010), but all were in a similar region, and several were based on small and medium-sized herds. The objective of this observational field study was to validate the relationship of selected serum metabolite concentrations with disease in early lactation across different regions and management systems. This study is novel in assembling a representative sample from most of the major dairy regions of the United States and Canada and, in contrast to a recent large field study (Ospina et al., 2010), it follows the same cohort of animals through the peripartum period.

\section{MATERIALS AND METHODS}

\section{Data Collection}

Fifty-five Holstein freestall dairy herds located across the United States and Canada were selected based on the herd managers' willingness to participate. Study herds were required to be enrolled in a milk recording service (DHI). Herds were recruited from 4 regions: Midwest (Minnesota and Wisconsin), Northeast (New York and Ontario, Canada), Southeast (Florida, Georgia, North Carolina, South Carolina, and Virginia), and West (California). Technicians visited each herd weekly, at the same time on the same day of the week.
The design was a cow-level study. To detect a difference in disease incidence of $4 \%$ versus $8 \%$ between groups, 552 cows per group were required (Dohoo et al., 2003). A sample of 30 cows per herd was sufficient to detect a prevalence of elevated metabolite concentration of $5 \%$ with $95 \%$ confidence. Therefore, the planned sample size was 552 cows per region for a total of 2,208 cows, with 30 cows and heifers per farm and approximately 20 herds per region. Animals were enrolled beginning $10 \mathrm{~d}$ before expected calving using lists generated from herd management software programs (DairyComp 305, Valley Ag Software, Tulare, CA; PC Dart, Dairy Records Management System, Raleigh, NC), with subsequent visits in wk 1, 2, and 3 after calving. During each visit, a 10-mL blood sample was collected from the same animals from the coccygeal vein or artery into an evacuated sterile tube without anticoagulant (Vacutainer, Becton-Dickinson, Franklin Lakes, NJ). The samples were kept chilled and allowed to clot. Blood was centrifuged and the serum was separated and stored at $-20^{\circ} \mathrm{C}$ within $8 \mathrm{~h}$ of collection. Body condition was scored at enrollment, on a scale of 1 (thin) to 5 (obese), using increments of 0.25 (Wildman et al., 1982). Herd managers recorded disease events with a standard sheet or in the farm computer, which included DA, dystocia, ketosis, mastitis, metritis, milk fever, and RP. Technicians educated herd managers using verbal discussion and information sheets on case definitions of disease events to standardize the information collected. The definitions of disease events are described in LeBlanc et al. (2002).

Serum samples were sent to the Animal Health Laboratory, University of Guelph, for analyses of NEFA, BHBA, and calcium concentrations. All biochemical tests were conducted on an automated analyzer (Hitachi 911 Analyzer, Randox, Laval, Quebec, Canada), using reagents supplied by Randox. Serum that was sent to Guelph from distant regions was packed in coolers to maintain $-20^{\circ} \mathrm{C}$ and shipped by overnight courier.

\section{Data Analysis}

Disease data were extracted from on-farm computer herd management software. Data were exported to SAS version 9.1 (SAS Institute Inc., Cary, NC) for statistical analysis. The cow was considered the experimental unit for all analyses. Clinical ketosis and mastitis cases were not consistently recorded across trial sites and therefore were not considered in the analyses. To maintain temporal associations between metabolites and disease, only samples that were taken before the disease occurred were considered predictors of disease. Because of the timing of occurrence of disease (Table 1), sample size decreased substantially for wk 2 and 3 relative to 
Table 1. Distribution of incidence risk of twins and postcalving disease, and median days to diagnosis (in parentheses when it applies) by study region

\begin{tabular}{|c|c|c|c|c|c|c|c|c|}
\hline Study region & $\begin{array}{c}\text { Herds } \\
\text { (no.) }\end{array}$ & $\begin{array}{c}\text { Total } \\
\text { cows (no.) }\end{array}$ & \multicolumn{6}{|c|}{ Incidence risk (\%) } \\
\hline Northeast & 20 & 662 & 3.8 & 8.2 & 5.4 & 2.0 & $6.2(5)$ & $5.0(12)$ \\
\hline Southeast & 10 & 494 & 1.2 & 8.7 & 7.3 & 1.8 & $17.4(7)$ & 4.1 (11) \\
\hline West & 8 & 653 & 2.6 & 25.1 & 9.0 & 2.6 & $35.7(6)$ & $0.5(19)$ \\
\hline
\end{tabular}

calving to the point that preliminary analyses indicated that there was little statistical power to address the objectives using the samples from those weeks. Therefore, these samples were not included in the final analyses. Because RP occurs by definition within $24 \mathrm{~h}$ after calving, only metabolite concentrations in wk -1 were considered as predictors for this disease. For each week of sampling (wk -1 and wk +1 relative to calving) and for each metabolite, a series of thresholds of concentrations was created for testing associations with disease outcomes. Initial screening of metabolite thresholds for simple associations with disease was performed with a Chi-squared test using $2 \times 2$ contingency tables. Among associations with $P<0.05$, the highest combined sensitivity $(\mathbf{S e})$ and specificity $(\mathbf{S p})$ was chosen to be the critical threshold and was used to categorize the concentrations of NEFA, BHBA, and calcium into high and low risk categories. Univariable associations between all cow-level covariates (listed below) and disease outcomes were tested with Chi-squared tests. Variables with $P<0.20$ in the initial screening were submitted to multivariable logistic regression (PROC GLIMMIX), using a binary distribution and logit link function. The outcomes of interest in the models were $\mathrm{RP}$, metritis and DA (binary variables) in the first 30 $\mathrm{d}$ after calving. Other diseases (dystocia, milk fever) were not considered further as outcome variables because they did not show any association with any of the metabolites in the exploratory analyses or recording was incomplete or inconsistent (clinical ketosis, mastitis), but they were considered as covariates. A final model was built for each disease of interest and week of sampling. The models included herd as a random effect, NEFA, BHBA, and calcium concentrations (categorized as binary variables) for the week of interest and the previous week (when wk +1 was the week of interest, wk -1 was included in the model), BCS (thin: $\leq 3.00$; moderate: 3.25 to 3.75 ; fat: $\geq 4.00)$, parity $(1,2$, or $\geq 3$ ), region (Midwest, Northeast, Southeast, West), season (warm = May through August 2006; cool = September 2006 through January 2007), twins, dystocia, and diseases (Table 1) that occurred before the disease of interest.
Stillbirth occurrence was not recorded consistently and was not included as a covariate. Length of the dry period was not recorded for inclusion as a covariate, because it would have required a larger sample size of multiparous cows to achieve our target statistical power. Variables were eliminated using a manual backward stepwise procedure, using $P \leq 0.05$ as the threshold for remaining in the model. Two-way interactions between the metabolites and the covariates that remained in the final model were tested and retained if $P \leq 0.05$.

\section{RESULTS}

In total, 2,365 cows were sampled across the 4 study regions between May 2006 and January 2007. The median number of cows sampled per herd was 36 (range of 21 to 91 ). Because of logistical limitations, fewer herds than initially planned were sampled in the Southeast and West regions, and more cows per herd were sampled to achieve the desired sample of cows per region. The study design was based on the cow as the unit of interest. Disease incidence risk and time of diagnosis by region are shown in Table 1.

\section{Retained Placenta}

The only metabolite associated with the risk of RP in the initial univariable screening was NEFA. The critical NEFA threshold for prediction of RP was $\geq 0.3 \mathrm{mEq} / \mathrm{L}$ ( $\mathrm{Se}=67 \% ; \mathrm{Sp}=46 ; 55 \%$ of cows above threshold). Serum NEFA concentration was the only variable that remained in the final model. Cows with serum NEFA concentrations above $\geq 0.3 \mathrm{mEq} / \mathrm{L}$ in wk -1 were 1.8 times more likely to retain the placenta after calving than cows with lower NEFA concentrations [odds ratio $(\mathbf{O R})=1.8 ; 95 \% \mathrm{CI}=1.3$ to $2.6 ; P<0.001]$.

\section{Metritis}

Because the apparent incidence of metritis was greater in the Western herds, the analyses were stratified into Western herds and the rest of the herds (Midwest, Northeast, and Southeast). The serum NEFA con- 
Table 2. Logistic regression model of the association of serum metabolites measured once in wk -1 relative to calving in Holstein cows in Western herds with the risk of subsequent diagnosis of metritis $(\mathrm{n}=653$ in 8 herds)

\begin{tabular}{|c|c|c|c|c|c|}
\hline Variable & Estimate & $\mathrm{SE}$ & $P$-value & $\begin{array}{l}\text { Odds } \\
\text { ratio }\end{array}$ & $\begin{array}{c}95 \% \\
\text { CI }\end{array}$ \\
\hline Intercept & -3.56 & 0.30 & 0.002 & - & - \\
\hline \multicolumn{6}{|l|}{ Body condition } \\
\hline Fat & -0.11 & 0.32 & 0.74 & 0.9 & $0.5-1.7$ \\
\hline Moderate & 0.49 & 0.22 & 0.03 & 1.6 & $1.1-2.5$ \\
\hline Thin & $\operatorname{Ref}^{1}$ & - & - & - & - \\
\hline \multicolumn{6}{|l|}{ Parity } \\
\hline 1 & 0.83 & 0.23 & 0.0002 & 2.3 & $1.5-3.6$ \\
\hline 2 & 0.62 & 0.24 & 0.009 & 1.9 & $1.2-2.9$ \\
\hline$\geq 3$ & Ref & - & - & - & - \\
\hline$\overline{\mathrm{Wk}}-1 \mathrm{NEFA} \geq 0.2 \mathrm{mEq} / \mathrm{L}$ & 0.51 & 0.20 & 0.01 & 1.7 & $1.1-2.5$ \\
\hline
\end{tabular}

centration in wk -1 was the only metabolite associated with the risk of metritis in the initial univariable screening. The critical prepartum NEFA threshold for prediction of metritis was $\geq 0.2 \mathrm{mEq} / \mathrm{L}(\mathrm{Se}=76 \%$; $\mathrm{Sp}$ $=36 ; 68 \%$ of cows above threshold) for the Western herds and $\geq 0.3 \mathrm{mEq} / \mathrm{L}(\mathrm{Se}=74.8 \%$; $\mathrm{Sp}=39.5 ; 61 \%$ of cows above threshold) for the rest of the herds. No significant relationships were found between postcalving serum metabolites and risk for diagnosis of metritis.

When the Western herds were modeled separately, BCS, parity, and precalving NEFA were associated with metritis (Table 2). When the remaining 3 regions were modeled together, season and precalving NEFA were associated with metritis (Table 3 ).

\section{Displaced Abomasum}

The critical threshold for prediction of DA in wk -1 and wk +1 relative to calving for the metabolites associated with the risk of DA in the initial univariable screening are in Table 4. The precalving multivariable logistic model showed that, controlling for region, serum NEFA $\geq 0.5 \mathrm{mEq} / \mathrm{L}$ was significantly associated with the development of DA (Table 5).

The postcalving multivariable logistic model showed that, controlling for region, precalving NEFA $\geq 0.5$ $\mathrm{mEq} / \mathrm{L}$ and postcalving NEFA $\geq 1.0 \mathrm{mEq} / \mathrm{L}$ and cal- cium $\leq 2.2 \mathrm{mmol} / \mathrm{L}$ were associated with subsequent risk of DA (Table 6). In 9 cases, the postcalving blood sample was collected after the occurrence of DA and therefore, these samples were not considered in the analyses.

\section{DISCUSSION}

This was a large, multi-region observational study in freestall dairy facilities in North America. Differences in natural resources, dairy farm structure, industry, and market have caused different regions to implement different management systems (Oleggini et al., 2001). With cows being managed under the herds' own protocols, this study provides unique insight into serum metabolite concentrations during the peripartum period.

The results generally support other reports on the predictive association of elevated NEFA and BHBA with the development of disease in the transition period (Cameron et al., 1998; LeBlanc et al., 2005; Ospina et al., 2010), confirming the previously reported association between indicators of energy metabolism and disease (Oetzel, 2004; Duffield et al., 2009).

The incidence of retained placenta was similar to what was reported by the National Animal Health Monitoring System (NAHMS, 2007). Other research has reported similar relationships between RP and serum NEFA

Table 3. Logistic regression model of the association of serum metabolites measured once in wk -1 relative to calving in Holstein cows in the Northeast, Midwest, and Southeast regions with the risk of subsequent diagnosis of metritis ( $\mathrm{n}=1,712$ in 47 herds)

\begin{tabular}{|c|c|c|c|c|c|}
\hline Variable & Estimate & $\mathrm{SE}$ & $P$-value & $\begin{array}{l}\text { Odds } \\
\text { ratio }\end{array}$ & $\begin{array}{c}95 \% \\
\text { CI }\end{array}$ \\
\hline Intercept & -3.52 & 0.27 & 0.0001 & - & - \\
\hline \multicolumn{6}{|l|}{ Season } \\
\hline Cool & 0.97 & 0.35 & 0.005 & 2.6 & $1.3-5.3$ \\
\hline Warm & $\operatorname{Ref}^{1}$ & - & - & - & - \\
\hline $\mathrm{Wk}-1 \mathrm{NEFA} \geq 0.3 \mathrm{mEq} / \mathrm{L}$ & 0.61 & 0.22 & 0.006 & 1.8 & $1.5-2.9$ \\
\hline
\end{tabular}

${ }^{1}$ Referent. 
Table 4. Sensitivity (Se) and specificity (Sp) of serum NEFA, BHBA, and calcium critical thresholds in wk -1 and wk +1 relative to calving for prediction of displaced abomasum ( $\mathrm{n}=2,365$ cows in 55 herds)

\begin{tabular}{|c|c|c|c|c|c|}
\hline Metabolite & $\begin{array}{l}\text { Critical } \\
\text { threshold }\end{array}$ & $\begin{array}{l}\text { Cows in the } \\
\text { higher risk } \\
\text { group (\%) }\end{array}$ & $\begin{array}{l}\mathrm{Se} \\
(\%)\end{array}$ & $\begin{array}{l}\mathrm{Sp} \\
(\%)\end{array}$ & $\begin{array}{l}\text { Odds } \\
\text { ratio }^{1}\end{array}$ \\
\hline \multicolumn{6}{|c|}{ NEFA $(\mathrm{mEq} / \mathrm{L})$} \\
\hline $\mathrm{Wk}-1$ & $\geq 0.5$ & 26 & 49 & 75 & 2.9 \\
\hline $\mathrm{Wk}+1$ & $\geq 1.0$ & 21 & 51 & 80 & 4.3 \\
\hline \multicolumn{6}{|c|}{$\mathrm{BHBA}(\mu \mathrm{mol} / \mathrm{L})$} \\
\hline $\mathrm{Wk}-1$ & $\geq 800$ & 8 & 22 & 93 & 3.7 \\
\hline $\mathrm{Wk}+1$ & $\geq 900$ & 32 & 57 & 69 & 2.9 \\
\hline \multicolumn{6}{|c|}{ Calcium $(\mathrm{mmol} / \mathrm{L})$} \\
\hline $\mathrm{Wk}-1$ & $\leq 2.35$ & 30 & 35 & 71 & 1.3 \\
\hline $\mathrm{Wk}+1$ & $\overline{\leq} 2.20$ & 38 & 64 & 63 & 3.0 \\
\hline
\end{tabular}

${ }^{1} P<0.001$ in all cases.

concentrations (LeBlanc et al., 2004; Quiroz-Rocha et al., 2010). LeBlanc et al. (2004) found that cows with precalving NEFA $\geq 0.5 \mathrm{mEq} / \mathrm{L}$ tended to be 1.8 times more likely to develop RP, whereas Quiroz-Rocha et al. (2010) found a $5 \%$ relative increase in the odds of $\mathrm{RP}$ for each $0.1 \mathrm{mEq} / \mathrm{L}$ increase in NEFA concentration in the week before calving. Ospina et al. (2010) found that cows with NEFA concentration $\geq 0.5 \mathrm{mEq} / \mathrm{L}$ within 14 $\mathrm{d}$ before calving had a 2.2 times greater risk of RP, metritis, or both. The relationship between fetal membrane expulsion and NEFA may be associated with the negative effect of NEFA on at least some aspects of immune function (Lacetera et al., 2005).

The diagnosis of metritis is challenging and inconsistent in commercial dairies (Sheldon et al., 2006) and is likely influenced by the transition management protocols. Although great efforts were taken to standardize disease definitions among farms, the methods of detection of disease varied among farms. The Western region had approximately double the incidence risk of metritis compared with the other 3 regions. Although high incidences were reported in the same region (22\%; Overton and Fetrow, 2008), different protocols for routine cow assessment could have increased the chances of detecting metritis in that region. Although the same case definition of metritis was employed on all farms, those in the Western region typically examined and took the temperature of each cow daily in early lactation for 7 to $10 \mathrm{~d}$ after calving, making detection of both fever and fetid vaginal discharge more likely, even though animals were not systematically palpated. Notwithstanding having the same disease criteria, it is likely that the systematic examination employed in those herds as opposed to examining only animals in which potential signs of illness were observed (e.g., dullness, lower than expected milk production, or fetid odor) led to a higher apparent incidence of metritis. Nevertheless, the threshold and magnitude of association of precalving NEFA with metritis were similar among regions.

Previous studies found relationships of precalving feed intake and energy metabolism with uterine disease (Hammon et al., 2006; Huzzey et al., 2007). Puerperal metritis was associated with a significant increase in NEFA concentrations and reduction in neutrophil function 2 wk before calving compared with cows that had normal uterine health (Hammon et al., 2006). These findings, as well as the results from this study, point to a relationship of decreased immune function and reduced adaptation of energy and lipid metabolism with subsequent uterine disease.

The incidence of DA and the median time to diagnosis supported other reports in the literature (Cameron

Table 5. Logistic regression model of the association of serum metabolites measured once in wk -1 relative to calving in Holstein cows with the risk of subsequent diagnosis of displaced abomasum ( $\mathrm{n}=2,365$ in 55 herds)

\begin{tabular}{lccccc}
\hline Variable & Estimate & $\mathrm{SE}$ & $P$-value & $\begin{array}{c}\text { Odds } \\
\text { ratio }\end{array}$ & $\begin{array}{c}95 \% \\
\text { CI }\end{array}$ \\
\hline $\begin{array}{l}\text { Intercept } \\
\text { Region }\end{array}$ & -3.56 & 0.30 & 0.0001 & - & - \\
$\quad$ Midwest & 0.39 & 0.36 & 0.27 & 1.5 & $0.7-2.8$ \\
$\quad$ Northeast & 0.17 & 0.35 & 0.62 & 1.2 & $0.6-2.3$ \\
West & -2.01 & 0.67 & 0.003 & 0.1 & $0.0-0.5$ \\
Southeast & $\operatorname{Ref}^{1}$ & - & - & - & - \\
Wk -1 NEFA $\geq 0.5 \mathrm{mEq} / \mathrm{L}$ & 0.88 & 0.23 & 0.0001 & 2.4 & $1.5-3.7$ \\
\hline
\end{tabular}

${ }^{1}$ Referent. 
Table 6. Logistic regression model of the association of serum metabolites measured once in each of wk -1 and wk +1 relative to calving in Holstein cows with the risk of subsequent diagnosis of displaced abomasum ( $\mathrm{n}=2,356$ cows in 55 herds)

\begin{tabular}{|c|c|c|c|c|c|}
\hline Variable & Estimate & $\mathrm{SE}$ & $P$-value & $\begin{array}{l}\text { Odds } \\
\text { ratio }\end{array}$ & $\begin{array}{c}95 \% \\
\text { CI }\end{array}$ \\
\hline Intercept & -4.39 & 0.35 & 0.0001 & - & - \\
\hline \multicolumn{6}{|l|}{ Region } \\
\hline Midwest & 0.40 & 0.37 & 0.28 & 1.5 & $0.7-3.1$ \\
\hline Northeast & 0.33 & 0.36 & 0.36 & 1.4 & $0.7-2.8$ \\
\hline West & -1.95 & 0.67 & 0.004 & 0.1 & $0.0-0.5$ \\
\hline Southeast & $\operatorname{Ref}^{1}$ & - & - & - & - \\
\hline Wk $-1 \mathrm{NEFA} \geq 0.5 \mathrm{mEq} / \mathrm{L}$ & 0.50 & 0.25 & 0.049 & 1.6 & $1.0-2.7$ \\
\hline $\mathrm{Wk}+1 \mathrm{NEFA} \geq 1.0 \mathrm{mEq} / \mathrm{L}$ & 1.12 & 0.25 & 0.0001 & 3.1 & $1.9-5.0$ \\
\hline $\mathrm{Wk}+1$ calcium $\leq 2.2 \mathrm{mmol} / \mathrm{L}$ & 0.99 & 0.25 & 0.0001 & 2.7 & $1.7-4.4$ \\
\hline
\end{tabular}

et al., 1998; LeBlanc et al., 2005). The Western region had a lower incidence of DA at $0.5 \%$ compared with the other 3 regions, similar to that found by Urdaz et al. (2006) in 1 herd in the same region. With DA being a multifactorial disease, several management, nutritional, and environmental factors may have contributed to the lower incidence rate in the Western region (Cameron et al., 1998).

The relationship between precalving NEFA concentrations $\geq 0.5 \mathrm{mEq} / \mathrm{L}$ and increased risk of $\mathrm{DA} 1$ to 2 wk later supports results of other studies (Cameron et al., 1998; LeBlanc et al., 2005; Ospina et al., 2010). Whereas LeBlanc et al. (2005) reported the same critical threshold as in the current study when sampling within 1 wk before calving, Cameron et al. (1998) and Ospina et al. (2010) reported lower critical thresholds ( $\geq 0.3$ and $\geq 0.27 \mathrm{mEq} / \mathrm{L}$, respectively). These differences are likely caused by the larger sampling frame of 35 to $3 \mathrm{~d}$ and 14 to $2 \mathrm{~d}$ precalving, respectively, because the increase in NEFA concentrations typically starts approximately 5 d before calving (LeBlanc et al., 2005). The present study found a univariable association between precalving BHBA $\geq 800 \mu \mathrm{mol} / \mathrm{L}$ and increased risk of DA. Both the specificity associated with this threshold and the number of cows above the threshold were low; therefore, results should be interpreted with caution.

LeBlanc et al. (2005) examined BHBA and NEFA concentrations in the first week after calving and found critical thresholds for DA prediction of $\geq 1,200 \mu \mathrm{mol} / \mathrm{L}$ and $\geq 1.0 \mathrm{mEq} / \mathrm{L}$, respectively. Similarly, Ospina et al. (2010) reported critical thresholds of $\geq 1,000 \mu \mathrm{mol} / \mathrm{L}$ and $\geq 0.72 \mathrm{mEq} / \mathrm{L}$, respectively. LeBlanc et al. (2005) found that BHBA was more sensitive and specific as a predictor of DA than NEFA concentration in wk 1 postcalving. On the other hand, Ospina et al. (2010) found that postcalving serum NEFA had a greater association with the risk of developing DA than precalving NEFA and postcalving BHBA. Whereas LeB- lanc et al. (2005) and Ospina et al. (2010) considered pre- and postcalving serum metabolite concentrations separately, the purpose of the current study was to evaluate the combinations of serum metabolites taken both before and after calving that would provide the most insight into the development of DA. In the model examining metabolite information from wk -1 to wk +1 relative to calving, elevated concentrations of NEFA before and after calving and lower calcium in the week postcalving (albeit within the reference range of 2.1 to $2.8 \mathrm{mmol} / \mathrm{L}$ ) were associated with an increased risk of DA. Elevated NEFA concentrations are associated with the potential for a reduction in liver function because of re-esterification of fatty acids and accumulation of triglycerides in the cytoplasm of hepatocytes, which could lead to a further decrease in DMI (Herdt, 2000). Longer periods of elevated NEFA concentrations may worsen the effects on the liver and subsequently lead to suboptimal DMI, contributing to the development of a DA. Massey et al. (1993) found that cows with serum calcium $<1.97 \mathrm{mmol} / \mathrm{L}$ at calving had an increased risk of developing DA, although LeBlanc et al. (2005) found no association. Reduced calcium concentrations have been associated with a reduction in rumen and abomasal motility, which in turn is thought to increase the risk of DA (Daniel, 1983). It is likely that calcium concentrations are an indicator of inadequate DMI, which most likely contributes to the development of DA. The present study confirmed a univariable association of high BHBA concentrations in early lactation with subsequent risk of DA at a threshold lower than that in previous reports (Oetzel, 2004; LeBlanc et al., 2005; Ospina et al., 2010). The present final model for DA does not refute subclinical ketosis in early lactation as a risk factor for DA, but provides new, more comprehensive data that NEFA concentrations in wk -1 and wk +1 relative to calving provide more information than BHBA, when both metabolites are considered together. 
Fatness was associated with an increased risk of developing disease postcalving (Fronk et al., 1980). No associations between precalving BCS $\geq 3.75$ and disease were found in this study. These findings do not refute the importance of body condition, but indicate the serum metabolites provide better insight into health status in the short-term.

In conclusion, elevated serum NEFA concentrations within 1 wk before calving are associated with increased risk of RP, metritis, and DA after calving. Serum NEFA and calcium concentrations in the 2 wk around calving in combination are associated with the risk of DA.

\section{ACKNOWLEDGMENTS}

The authors are grateful to Pfizer Animal Health (New York, NY) for providing financial support for this project. The authors acknowledge the farmers, veterinarians, and technical staff for their participation in the project. Núria Chapinal was supported by a Beatriu de Pinós postodoctoral grant from the Generalitat de Catalunya.

\section{REFERENCES}

Bauman, D. E., and W. B. Currie. 1980. Partitioning of nutrients during pregnancy and lactation: A review of mechanisms involving homeostasis and homeorhesis. J. Dairy Sci. 63:1514-1529.

Cameron, R. E. B., P. B. Dyk, T. H. Herdt, J. B. Kaneene, R. Miller, H. F. Bucholtz, J. S. Liesman, M. J. Vandehaar, and R. S. Emery. 1998. Dry cow diet, management, and energy balance as risk factors for displaced abomasum in high producing dairy herds. J. Dairy Sci. 81:132-139.

Carrier, J., S. Stewart, S. Godden, J. Fetrow, and P. Rapnicki. 2004. Evaluation and use of three cowside tests for detection of subclinical ketosis in early postpartum cows. J. Dairy Sci. 87:3725-3735.

Daniel, R. C. W. 1983. Motility of the rumen and abomasums during hypocalcemia. Can. J. Comp. Med. 47:276-280.

Dohoo, I., W. Martin, and H. Stryhn. 2003. Veterinary Epidemiologic Research. AVC Inc., Charlottetown, PEI, Canada.

Duffield, T. F., K. D. Lissemore, B. W. McBride, and K. E. Leslie. 2009. Impact of hyperketonemia in early lactation dairy cows on health and production. J. Dairy Sci. 92:571-580.

Fronk, T. J., L. H. Schultz, and A. R. Hardie. 1980. Effect of dry period overconditioning on subsequent metabolic disorders and performance of dairy cows. J. Dairy Sci. 63:1080-1090.

Goldhawk, C., N. Chapinal, D. M. Veira, D. M. Weary, and M. A. G. von Keyserlingk. 2009. Prepartum feeding behaviour as an early indicator of subclinical ketosis. J. Dairy Sci. 92:4971-4977.

Hammon, D. S., I. M. Evjen, T. R. Dhiman, J. P. Goff, and J. L. Walters. 2006. Neutrophil function and energy status in Holstein cows with uterine health disorders. Vet. Immunol. Immunopathol. 113:21-29.
Hayirli, A., R. R. Grummer, E. V. Nordheim, and P. M. Crump. 2002. Animal and dietary factors affecting feed intake during the prefresh transition period in Holsteins. J. Dairy Sci. 85:3430-3443.

Herdt, T. H. 2000. Ruminant adaptation to negative energy balance. Vet. Clin. North Am. Food Anim. Pract. 16:215-230.

Huzzey, J. M., D. M. Veira, D. M. Weary, and M. A. G. von Keyserlingk. 2007. Prepartum behavior and dry matter intake identify dairy cows at risk for metritis. J. Dairy Sci. 90:3220-3233.

Lacetera, N., D. Scalia, U. Bernabucci, B. Ronchi, D. Pirazzi, and A. Nardone. 2005. Lymphocyte functions in overconditioned cows around parturition. J. Dairy Sci. 88:2010-2016.

LeBlanc, S. J., T. F. Duffield, K. E. Leslie, K. G. Bateman, J. TenHag, J. S. Walton, and W. H. Johnson. 2002. The effect of prepartum injection of vitamin $\mathrm{E}$ on health of transition dairy cows. J. Dairy Sci. 85:1416-1426.

LeBlanc, S. J., T. H. Herdt, W. M. Seymour, T. F. Duffield, and K. E. Leslie. 2004. Peripartum serum vitamin E, retinol, and $\beta$-carotene in dairy cattle and their associations with disease. J. Dairy Sci. 87:609-619.

LeBlanc, S. J., K. E. Leslie, and T. F. Duffield. 2005. Metabolic predictors of displaced abomasum in dairy cattle. J. Dairy Sci. $88: 159-170$.

LeBlanc, S. J., K. D. Lissemore, D. F. Kelton, T. F. Duffield, and K. E. Leslie. 2006. Major advances in disease prevention in dairy cattle. J. Dairy Sci. 89:1267-1279.

Massey, C. D., C. Wang, G. A. Donovan, and D. K. Beede. 1993. Hypocalcemia as a risk factor for left displacement of the abomasum in dairy cows. J. Am. Vet. Med. Assoc. 203:852-853.

National Animal Health Monitoring System (NAHMS). 2007. Part 1: Reference of Dairy Health and Management in the United States. USDA-APHIS Veterinary Services, Ft. Collins, CO.

Oetzel, G. R. 2004. Monitoring and testing dairy herds for metabolic disease. Vet. Clin. North Am. Food Anim. Pract. 20:651-674.

Oleggini, G. H., L. O. Ely, and J. W. Smith. 2001. Effect of region and herd size on dairy herd performance parameters. J. Dairy Sci. 84:1044-1050.

Ospina, P. A., D. V. Nydam, T. Stokol, and T. R. Overton. 2010. Evaluation of nonesterified fatty acids and $\beta$-hydroxybutyrate in transition dairy cattle in the northeastern United States: Critical thresholds for prediction of clinical diseases. J. Dairy Sci. 93:546-554.

Overton, M., and J. Fetrow. 2008. Economics of postpartum uterine health. Pages 39-43 in Dairy Cattle Reproduction Council Annual Meeting and Convention, Omaha, NE.

Quiroz-Rocha, G. F., S. J. LeBlanc, T. F. Duffield, B. Jefferson, D. Wood, K. E. Leslie, and R. M. Jacobs. 2010. Effect of sampling time relative to the first daily feeding on interpretation of serum fatty acid and $\beta$-hydroxybutyrate concentrations in dairy cattle. J. Dairy Sci. 93:2030-2033.

Sheldon, I. M., G. S. Lewis, S. LeBlanc, and R. O. Gilbert. 2006. Defining postpartum uterine disease in cattle. Theriogenology 65:1516-1530.

Urdaz, J. H., M. W. Overton, D. A. Moore, and J. E. P. Santos. 2006. Technical note: Effects of adding shade and fans to a feedbunk sprinkler system for preparturient cows on health and performance. J. Dairy Sci. 89:2000-2006.

Wildman, E. E., G. M. Jones, P. E. Wagner, R. L. Boman, H. F. Troutt Jr., and T. N. Lesch. 1982. A dairy cow body condition scoring system and its relationship to selected production characteristics. J. Dairy Sci. 65:495-501. 